\title{
Prevalence of iron-deficiency anemia in children aged less than 60 months: A population-based study from the state of Minas Gerais, Brazil
}

\section{in}

Prevalência de anemia ferropriva em crianças

menores de 60 meses: estudo de base

populacional no Estado de

Minas Gerais, Brasil

\author{
Maria Beatriz Monteiro de Castro LISBÔA ${ }^{1}$ \\ Edilson Ornelas OLIVEIRA ${ }^{2}$ \\ Joel Alves LAMOUNIER ${ }^{3}$ \\ Camilo Adalton Mariano SILVA 4 \\ Renata Nascimento FREITAS 1,4
}

\section{A B S T R A C T}

\section{Objective}

To identify the prevalence of iron-deficiency anemia in children aged less than 60 months and the conditioning factors in Minas Gerais, Brazil.

\section{Methods}

This cross-sectional study conducted from February 2007 to July 2008 in Minas Gerais included a random sample of 725 male and female children aged less than 60 months. A household survey was administered to the children's parents or guardians to collect socioeconomic, demographic, food security, and the child's anthropometric data. The hemoglobin level was determined by a portable hemoglobinometer. Anemia was considered present when hemoglobin levels were below $11.0 \mathrm{~g} / \mathrm{dL}$. Statistical analyses estimated the prevalence

${ }^{1}$ Universidade Federal de Ouro Preto, Núcleo de Pesquisas em Ciências Biológicas, Programa de Pós-Graduação em Ciências

Biológicas. Ouro Preto, MG, Brasil.

2 Fundação Hospitalar do Estado de Minas Gerais, Hospital Infantil João Paulo II. Ouro Preto, MG, Brasil.

3 Universidade Federal de São João Del Rei, Departamento de Medicina. Divinópolis, MG, Brasil.

${ }^{4}$ Universidade Federal de Ouro Preto, Escola de Nutrição, Departamento de Nutrição Clínica e Social. Campus Universitário Morro do Cruzeiro, Bairro Bauxita, 35400-000, Ouro Preto, MG, Brasil. Correspondência para/Correspondence to: RN FREITAS.

E-mail: <renata@enut.ufop.br>. 
of anemia and its association with socioeconomic, demographic, and food security-related variables. The model was adjusted by multivariate logistic regression. The significance level was set at $5 \%(p<0.05)$.

\section{Results}

The prevalence of anemia was $37.4 \%$. The greatest prevalence occurred in the age group 6 to 24 months (43.0\%). The associated variables were being female $(P R=1.43 ; p<0.026)$; age $(P R=1.53 ; p<0.024)$; and not frequenting a daycare center $(P R=2.41 ; p<0.001)$. In the multivariate regression model, the variables being female and not frequenting a daycare center remained in the model.

\section{Conclusion}

The present population-based study found that in Minas Gerais, one-third (37.5\%) of the children aged less than 60 months have iron-deficiency anemia. The results show that not frequenting a daycare center and being female are risk factors for anemia.

Keywords: Anemia iron-deficiency. Food security. Prevalence. Risk factors.

\section{R E S U M O}

\section{Objetivo}

Identificar a prevalência de anemia em crianças menores de 60 meses e seus fatores condicionantes, em Minas Gerais.

\section{Métodos}

Estudo transversal com amostra probabilística de 725 crianças menores de 60 meses de idade, de ambos os sexos, realizado entre fevereiro de 2007 e julho de 2008, em Minas Gerais. Por meio de inquérito domiciliar aplicado aos responsáveis pelas crianças, foram obtidas informações sobre as condições socioeconômicas, demográficas e situação de segurança alimentar, bem como obtidas as medidas antropométricas. A dosagem de hemoglobina foi analisada em hemoglobinômetro portátil, considerando-se como anemia valor $<11,0 \mathrm{~g} /$ $d L$. A análise estatística estimou a prevalência da anemia e sua associação com condições socioeconômicas, demográficas e segurança alimentar. O modelo foi ajustado por regressão logística multivariada. Adotou-se p<0,05 como nível crítico para definir significância estatística.

\section{Resultados}

A prevalência de anemia foi de 37,4\%. A maior prevalência ocorreu na faixa etária de 6 a 24 meses (43,0\%). As variáveis associadas foram: sexo feminino $(R P=1,43 ; p<0,026)$; idade $(R P=1,53 ; p<0,024)$ e não frequentar creche $(R P=2,41 ; p<0,001)$. No modelo de regressão multivariada, permaneceram as variáveis sexo feminino e não frequentar creche.

\section{Conclusão}

O presente estudo, de base populacional, mostrou que em Minas Gerais um terço das crianças (37,5\%) com menos de 60 meses de idade apresentava anemia ferropriva. Os resultados revelaram que não frequentar creche e ser do sexo feminino configuram situações de risco à ocorrência de anemia.

Palavras-chave: Anemia ferropriva. Segurança alimentar e nutricional. Prevalência. Fatores de risco.

\section{INTRODUCTION}

Anemia caused by iron deficiency, irondeficiency anemia, is the most important nutrition problem in the world ${ }^{1}$. Despite the considerable economic and scientific development seen in the last decades regarding anemia, its global prevalence decreased only marginally. Estimates of the World Health Organization (WHO) indicate that $24.8 \%$ of the world population, that is, almost one-fourth of the population, is anemic ${ }^{2}$. Iron-deficiency anemia is defined as a serum hemoglobin level below $11.0 \mathrm{~g} / \mathrm{dL}$. The highest prevalences are found in children younger than 5 years of age and pregnant women 1 . In developing countries, $47.4 \%$ of the children in the $0-4$ years' age group are anemic ${ }^{1}$.

Iron-deficiency anemia stems from an unbalance between the amount of bioavailable 
iron absorbed from food and the body's requirement. It represents the final manifestation of iron deficiency, characterized by small red blood cells because of inadequate hemoglobin, significant reduction in the body's iron reserves, and low hematocrit ${ }^{2}$. Iron is involved in many metabolic and oxidation reactions and is essential for mitosis. Once the deficiency during childhood sets in and remains for a long time, the health consequences are severe. The following changes have been observed: late psychomotor development, difficulties in language acquisition, significant loss of cognition, greater susceptibility to infections, fatigue, and irritability ${ }^{3}$.

In Brazil the National Survey of Child and Woman Demography and Health ${ }^{4}$ identified a prevalence of anemia of $20.9 \%$ in children aged less than 59 months, and the highest prevalence was in children aged less than 24 months (24.1\%) followed by children aged 24-59 months (19.5\%). A study conducted in the state of Pernambuco ${ }^{5}$ with urban and rural representativeness found a prevalence of $32.8 \%$ in children aged 6 to 59 months without a significant difference between areas. In another population-based study in an urban area of the municipality of Criciúma (SC) with children aged less than 36 months, the prevalence of anemia was $54.0 \%$ and according to the authors, the highest prevalence was found in the 12-18 month age group ${ }^{6}$.

In Minas Gerais studies conducted in different municipalities found prevalences that varied from $26.0 \%$ in two-year-olds ${ }^{7}$ to $60.8 \%$ in infants aged 6-12 months ${ }^{8}$. However, there is no population-based data for children aged less than 60 months. Hence, the objective of this study was to identify the prevalence of iron-deficiency anemia in this age group and the associated factors.

\section{METHODS}

This is a subproject of a wider study called "Health and nutritional status of women aged 15 to 49 years and children aged less than 60 months from Minas Gerais: prevalence of obesity, iron-deficiency anemia, food security, and their economic determinants". A descriptive crosssectional study was conducted with a probabilistic sample of children aged less than 60 months and women aged 15 to 49 years by the Food and Nutrition Coordination of the State Department of Minas Gerais.

The state of Minas Gerais is located in the southeastern region of Brazil. It has a population of $20,593,366$ inhabitants, of which $85.6 \%$ live in urban areas $^{9}$. The mean per capita income in 2009 was $R \$ 773.41$, ranking the state eleventh among Brazilian states ${ }^{9}$.

The municipalities were chosen based on the decision to work with the same municipalities included in the "Project SB2000: A perspective for the consolidation of epidemiology in public oral health", a study done in 2000 by the Ministry of Health ${ }^{10}$. The said study followed the logic of stratification proposed by Roncalli et al. ${ }^{10}$, dependent on population size. The 853 municipalities of Minas Gerais were stratified and their contribution to the total inhabitants of the state, calculated. Next the number of municipalities were selected randomly for each population stratum, that is, eight municipalities with up to 5,000 inhabitants were selected, representing $29.6 \%$; five municipalities with 5,001 to 10,000 inhabitants were selected, representing $18.8 \%$, and 14 municipalities with up to 10,000 inhabitants of a total of 27 municipalities.

Representative samples of women aged 15 to 49 years and children aged less than 60 months were calculated for the 27 municipalities. Since there are no representative populationbased studies about iron-deficiency anemia for the state of Minas Gerais, we considered an expected prevalence of $50 \%$ for this morbidity for children aged less than 60 months with a significance level of $95 \%$. The effect of the sampling plan was given by expressions published by $\mathrm{Katz}^{11}$, resulting in a minimum sample of 600 children and 1,200 women. A design effect equal 
to 1.8 was used to make up for sample losses such that the maximum stipulated sample was of 1,000 children and 1,200 women, with an error margin smaller than $4 \%$.

Next the number of census tracts in each municipality was systematically drawn, proportional to the rural and urban population, with a total of 200 census tracts. This number was then used to define the number of households per tract, that is, each municipality has a total number of census tracts $(N)$ and a number to be sampled (n), so that the sampling factor is $K=N / n$, reaching a total of 10 households per sector. To get to the household, we first obtained from the Brazilian Institute of Geography and Statistics the census tract maps to number the blocks from left to right and the respective outlines (beginning at the left and continuing clockwise). After numbering the blocks in each census tract, the blocks were drawn, three blocks from each sector. In the field all households in the selected block were counted and numbered. From this total $(\mathrm{N})$, we found the multiple value $(K)$ to perform the systematic sampling: $K=N / 10$, drawing a number between 1 and $K$ to be the first sampled household. We add $K$ to this first number to get the next household and so on until ten households were sampled. If a household had no children or women aged 15 to 49 years, the household right next to it was selected, always in a clockwise fashion. If a block did not have ten households, we would go to the second previously drawn block, and if necessary, up to the third also previously selected. The children eligible for the study were those in good general condition aged less than 60 months.

The data were collected from February 2007 to July 2008 using a questionnaire about food security and forms for recording information about the household, economic aspects, the child (frequenting a daycare center and having meals at the facility), anthropometry, and hemoglobin level. After presenting the study objectives and obtaining signed consent from the child's parents or guardians, the team supervisor interviewed them, and nursing/nutrition students performed the other procedures at the child's home. The entire field team was trained for the study. The socioeconomic data collected were: family income in Minimum Salaries (MS), education level of the family head (in years), number of rooms, and number of people in the household.

Food security was assessed by the Escala Brasileira de Insegurança Alimentar (EBIA, Brazilian Scale of Food Insecurity). EBIA is a subjective method for assessing how the families feel and react before the expectation of food (in)security, that is, before the risk of experiencing hunger ${ }^{12}$. It consists of a standardized questionnaire with 15 questions for the household's cook, measuring the concept of food security/food insecurity at different levels according to the interviewee's perception ${ }^{13}$. The scale allows the determination of the family's food security level by quantifying the total number of affirmative answers, that is, each affirmative answer receives a score of one. The scale score is given by adding the answer scores so it ranges from zero to fifteen points: zero (0): food security; 11-15 points: severe food insecurity.

The question regarding Exclusive Breastfeeding (EB) followed the recommendation of the Pan American Health Organization/World Health Organization (WHO): exclusive feeding with breast milk complemented with no other fluid or solid, except vitamins, minerals, or medications $^{14}$.

Weight was measured by a digital scale of the brand Kratos, model Linea, with capacity of $150 \mathrm{~kg}$ and accuracy of $0.1 \mathrm{~kg}$. The children were weighed barefoot wearing minimal clothing. Children younger than 24 months were weighed naked by a scale coupled with a pediatric cradle, following the manufacturer's recommendation. Their length was measured by an anthropometer for children measuring $1.5 \mathrm{~m}$ and millimetric accuracy. Children aged more than 24 months were measured by a portable stadiometer of the brand Altura Exata, also with millimetric accuracy. 
The anthropometric data were collected as recommended by Jellife ${ }^{15}$. Nutritional status was classified according to the child's weight-for-age and height-for-age in Z-scores, as proposed by the $\mathrm{WHO}^{16}$. The child's weight-for-age was classified as follows: $-3 \leq Z$-score $<-2$ as underweight for age; $-2 \leq Z$-score $\leq 2$ as normal weight for age; and $2<Z$-score $\leq 3$ as overweight for age. The child's height-for-age was classified as follows: Z-score $<-3$ as severely stunted; $-3 \leq$ Z-score $<-2$ as stunted; and Z-score $\geq-2$ as adequate height.

The hemoglobin level was determined by drawing blood by skin puncture and analyzing it with a high precision portable photometer of the brand HemoCue AB AngelholmnSweden (Blood Hemoglobin Photometer). Anemia was defined as a hemoglobin level smaller than $11 \mathrm{~g} / \mathrm{dL}$, as recommended by the $\mathrm{WHO}^{1}$.

In order to identify possible age-related risk factors for the occurrence of anemia, the sample was stratified into the following age groups: 0 to 6 months; 6 to 24 months; and 24 to 60 months.

The questionnaires were digitized and stored in the database Access 2008. Before the analyses, the database was verified for consistency and possible typing errors. In the case of inconsistencies (validation was done by Access), the original files were consulted for corrections. Nutritional status was assessed by the software Anthro, distributed by the WHO using WHO-2006's anthropometric standard.

The statistical analysis was performed by the program $R$. The global prevalence of iron-deficiency anemia was estimated according to socioeconomic variables, crude and adjusted prevalence ratios, and their respective confidence intervals. Confounding factors were controlled by adjusting the model by unconditional multivariate regression, making anemia the dependent variable.

The variables that presented statistical association with $p<0.20$ in univariate regression and some variables that the literature considered important risk factors for anemia, such as number of persons in household, breastfeeding, income, and education level, were selected for multivariate analysis to verify their independent effect on the study condition.

In multivariate analysis a complete model was composed, incorporating all variables previously selected and excluding those that were successively discarded by the initial model. In this

Table 1. Description of the sample according to socioeconomic, demographic, nutritional status, and living condition characteristics. Minas Gerais (2007).

\begin{tabular}{|c|c|c|}
\hline Characteristic & $\mathrm{N}$ & $\%$ \\
\hline \multicolumn{3}{|l|}{ Gender } \\
\hline Male & 350 & 48.3 \\
\hline Female & 375 & 51.7 \\
\hline \multicolumn{3}{|l|}{ Age (months) } \\
\hline Up to 6 & 104 & 14.3 \\
\hline$>6,01 \leq 24$ & 228 & 31.4 \\
\hline$>24,01$ & 393 & 54.2 \\
\hline \multicolumn{3}{|l|}{ Scholarity } \\
\hline Illiterate & 21 & 2.9 \\
\hline Basic Education & 370 & 51.1 \\
\hline High School & 274 & 37.8 \\
\hline Undergraduation & 60 & 8.3 \\
\hline \multicolumn{3}{|c|}{ Family income (minimum wage) } \\
\hline$<1,0$ & 145 & 20.0 \\
\hline$\geq 1,01<2,0$ & 273 & 37.7 \\
\hline$\geq 2,01$ & 307 & 42.3 \\
\hline \multicolumn{3}{|c|}{ Number of domicile rooms } \\
\hline One & 6 & 0.8 \\
\hline Two & 25 & 3.4 \\
\hline Three & 81 & 11.2 \\
\hline More than three & 613 & 84.6 \\
\hline \multicolumn{3}{|l|}{ Number of dweller } \\
\hline Two & 11 & 1.5 \\
\hline Three & 169 & 23.3 \\
\hline Four & 231 & 31.9 \\
\hline Five or more & 314 & 43,4 \\
\hline \multicolumn{3}{|c|}{ Nutrional status: height/age } \\
\hline$<-3 S Z$ & 24 & 3.3 \\
\hline$\geq-3$ e $<-2 S Z$ & 42 & 5.7 \\
\hline$\geq-2 S Z$ & 659 & 90.8 \\
\hline \multicolumn{3}{|l|}{ Weight/age } \\
\hline$\geq-3$ e $<-2 S Z$ & 35 & 4.8 \\
\hline$\geq-2$ e $<2 S Z$ & 649 & 89.5 \\
\hline$>2 S Z$ e $\leq 3 S Z$ & 41 & 5.6 \\
\hline
\end{tabular}


process the variables whose prevalence ratios and confidence intervals did not change significantly were maintained until a final model was obtained. This model was assessed by Prevalence Ratio (PR) and a Confidence Interval of $95 \%$.

The study followed the regular research norms involving human beings, Resolution no 196/ 96 from the National Health Council, and was authorized by the Research Ethics Committee of Hospital Eduardo de Menezes of the Hospital Foundation of the State of Minas Gerais under Protocol number 109/07.
The children with hemoglobin level below $11 \mathrm{~g} / \mathrm{dL}$ were sent, along with their record, to the health unit nearest to their home for treatment.

\section{RE S U LT S}

A total of 725 children were assessed, representing a greater number than the number of children needed for the minimum sample size for the $\mathbf{2 7}$ municipalities selected for the study. The losses were due to refusal to participate in the study. The mean age was 27.5 months

Table 2. Prevalence of anemia in children aged less than 60 months according to demographic and socioeconomic variables. Minas Gerais (2007).

\begin{tabular}{|c|c|c|c|c|c|c|c|}
\hline \multirow{3}{*}{ Variables } & \multicolumn{4}{|c|}{ Anemia } & \multirow{3}{*}{$p$-value } & \multirow{3}{*}{$P R$} & \multirow{3}{*}{$95 \% \mathrm{Cl}$} \\
\hline & \multicolumn{2}{|c|}{ Yes } & \multicolumn{2}{|c|}{ No } & & & \\
\hline & $\mathrm{n}$ & $\%$ & $n$ & $\%$ & & & \\
\hline \multicolumn{8}{|l|}{ Gender } \\
\hline Male & 117 & 33.4 & 233 & 66.6 & $0.038^{*}$ & 1.00 & \\
\hline Female & 154 & 41.1 & 221 & 58.9 & & 1.38 & $1.02-1.87$ \\
\hline Total & 271 & 37.4 & 454 & 62.6 & & & \\
\hline \multicolumn{8}{|l|}{ Age (months) } \\
\hline Up to 6 & 44 & 42.3 & 60 & 57.7 & 0.024 & 1.49 & $0.96-2.32$ \\
\hline$>6,01 \leq 24$ & 98 & 43.0 & 130 & 57.0 & & 1.53 & $1.09-2.15$ \\
\hline$>24,01$ & 129 & 32.9 & 263 & 67.1 & & & \\
\hline \multicolumn{8}{|l|}{ Household scholarity responsible } \\
\hline Illiterate & 11 & 52.4 & 10 & 47.6 & 0.437 & 2.04 & $0.74-5.59$ \\
\hline Basic Education complete/incomplete & 142 & 38.4 & 228 & 61.6 & & 1.15 & $0.65-2.04$ \\
\hline High School & 97 & 35.4 & 177 & 64.6 & & 1.01 & $0.56-1.82$ \\
\hline Undergraduation & 21 & 35.0 & 39 & 65.0 & & 1.00 & \\
\hline \multicolumn{8}{|l|}{ Family income (minimum wage) } \\
\hline$<1,0$ & 55 & 37.9 & 90 & 62.1 & 0.355 & 1.15 & $0.76-1.74$ \\
\hline$\geq 1,1<2,0$ & 110 & 40.3 & 163 & 59.7 & & 1.28 & $0.91-1.79$ \\
\hline$\geq 2,1$ & 106 & 34.5 & 201 & 65.5 & & 1.00 & \\
\hline \multicolumn{8}{|l|}{ Number of domicile rooms } \\
\hline One & 4 & 66.7 & 2 & 33.3 & 0.560 & 3.40 & $0.61-18.71$ \\
\hline Two & 10 & 40.0 & 15 & 60.0 & & 1.13 & $1.50-2.26$ \\
\hline Three & 30 & 37.0 & 51 & 63.0 & & 1.00 & $0.61-1.61$ \\
\hline More than three & 227 & 37.0 & 386 & 63.0 & & 1.00 & \\
\hline \multicolumn{8}{|l|}{ Number of dweller } \\
\hline Two & 3 & 27.3 & 8 & 72.7 & 0.693 & 1.00 & \\
\hline Three & 58 & 34.3 & 111 & 65.7 & & 1.39 & $0.35-5.45$ \\
\hline Four & 89 & 38.5 & 142 & 61.5 & & 1.67 & $0.43-6.46$ \\
\hline Five or more & 121 & 38.5 & 193 & 61.5 & & 1.67 & $0.43-6.42$ \\
\hline
\end{tabular}

Note: *Fischer's exact test.

PR: Prevalence Ratio; 95\% Cl: 95\% Confidence Interval. 
(Standard Deviation-SD=17.3 months), and the percentage of males was slightly smaller (48.3\%) (Table 1).

The prevalence of anemia in the total sample was $37.4 \%$. The highest prevalence was $43.0 \%$ in the age group 6-24 months (Table 2). Some $(4.8 \%)$ children were underweight for their age according to the weight-for-age indicator, and $5.7 \%$ were overweight. According to the weightfor-height indicator, $7.9 \%$ of the children were overweight. The nutritional indicators were not associated with anemia regardless of situation (Table 3).

The final model was constructed by selecting the variables statistically $(p<0.05)$ associated with anemia, namely gender, age group, and not frequenting a daycare center, and the variables with $p<0.20$ (food security and weight-for-height).

Table 4 shows the variables that remained in the adjusted multivariate regression model. After adjustment for the variables of the same level, age lost its statistical significance, and being female and not frequenting a daycare center remained associated with anemia.

\section{DISCUSSION}

The present population-based study showed that more than one third $(37.4 \%)$ of the children under 60 months of age from the state of Minas Gerais are anemic. Although deficiency of other nutrients may determine anemia, irondeficiency is by far the most common cause in

Table 3. Prevalence of anemia in children aged less than 60 months according to frequenting a daycare center status, breastfeeding status, food security level, and nutritional status. Minas Gerais (2007).

\begin{tabular}{|c|c|c|c|c|c|c|c|}
\hline \multirow{3}{*}{ Variables } & \multicolumn{4}{|c|}{ Anemia } & \multirow{3}{*}{$p$-value } & \multirow{3}{*}{$P R$} & \multirow{3}{*}{$95 \% \mathrm{Cl}$} \\
\hline & \multicolumn{2}{|c|}{ Yes } & \multicolumn{2}{|c|}{ No } & & & \\
\hline & $\mathrm{n}$ & $\%$ & $\mathrm{n}$ & $\%$ & & & \\
\hline \multicolumn{8}{|c|}{ Scholl/daycare center } \\
\hline Yes & 34 & 22.7 & 116 & 77.3 & $<0.001^{*}$ & 1.00 & - \\
\hline No & 237 & 41.3 & 338 & 58.8 & & 2.39 & $1.57-3.62$ \\
\hline \multicolumn{8}{|l|}{ Meals at home? } \\
\hline Yes & 32 & 22.4 & 111 & 77.6 & $<0.001^{*}$ & 1.00 & - \\
\hline No & 239 & 41.1 & 343 & 58.9 & & 2.41 & $1.57-3.70$ \\
\hline \multicolumn{8}{|c|}{ Exclusive breastfeeding } \\
\hline Yes & 237 & 38.1 & 385 & 61.9 & 0.323 & 0.80 & $0.51-1.24$ \\
\hline No & 34 & 33.0 & 69 & 67 & & 1.00 & - \\
\hline \multicolumn{8}{|l|}{ Food security } \\
\hline Security & 112 & 34.4 & 214 & 65.6 & 0.167 & 1.00 & - \\
\hline Severe insecurity & 24 & 47.1 & 27 & 52.9 & & 1.69 & $0.93-3.08$ \\
\hline \multicolumn{8}{|l|}{ Height/age } \\
\hline$<-3 S Z$ & 10 & 41.7 & 14 & 58.3 & 0.901 & 1.20 & $0.52-2.75$ \\
\hline$\geq-3$ e $<-2$ & 16 & 38.1 & 26 & 61.9 & & 1.04 & $0.54-1.97$ \\
\hline$\geq-2 S Z$ & 245 & 37.2 & 414 & 62.8 & & 1.00 & - \\
\hline \multicolumn{8}{|l|}{ Weight/age } \\
\hline$\geq-3$ e $<-2 S Z$ & 11 & 31.4 & 24 & 68.6 & 0.675 & 1.00 & - \\
\hline$\geq-2 \mathrm{SZ}$ e $<2 \mathrm{SZ}$ & 246 & 37.9 & 403 & 62.1 & & 1.33 & $0.64-2.76$ \\
\hline$>+2 \mathrm{SZ}$ e $\leq 3 \mathrm{SZ}$ & 14 & 34.1 & 27 & 65.9 & & 1.13 & $0.43-2.96$ \\
\hline
\end{tabular}

Note: "Fischer's exact test.

PR: Prevalence Ratio; 95\% Cl: 95\% Confidence Interval. 
Table 4. Prevalence ratio of anemia adjusted for multivariate regression model. Minas Gerais (2007).

\begin{tabular}{lcc}
\hline Characteristics & Adjusted Prevalence Ratio $(95 \% \mathrm{Cl})$ & $p$-value \\
\hline Gender & & 0.026 \\
Male & 1.00 & \\
Female & $1.43(1.03-1.90)$ & $<0.001$ \\
Scholl/daycare center & 1.00 & \\
Yes & $2.41(1.16-3.66)$ & \\
No & & \\
\hline
\end{tabular}

Note: $95 \% \mathrm{Cl}: 95 \%$ Confidence Interval.

regions where the prevalence of anemia is high ${ }^{17}$. Therefore, the terms anemia and iron-deficiency anemia are used interchangeably in public health; according to the WHO, anemia is synonymous with iron-deficiency anemia ${ }^{18}$. With parameters defined by the $\mathrm{WHO}$, this prevalence represents a moderate public health problem in the state ${ }^{19}$.

Studies in different Brazilian municipalities found similar results, with anemia being significantly associated with more individuals per household and worse education level of the family head $^{20,21}$. However, in this study, these variables were not associated with anemia. The study concludes that frequenting a daycare center or similar institutions in Minas Gerais during the study age (first 60 months of life) was protective because the prevalence of anemia in children who did not frequent a daycare center $(41.3 \%)$ was almost double of those who did (22.7\%) and had meals in schools.

Daycare centers are institutions that care for children aged zero to three years and preschoolers aged four to six years. They are an option for the population given the new socioeconomic reality of the last decades. Since children remain in a daycare center from eight to ten hours a day, this facility has an important role in the child's formation, improving their health since in addition to education, the children receive basic health care and quality meals that satisfy their nutritional needs ${ }^{22}$. Studies conducted in the state of Paraiba and in the municipality of Viçosa (MG), with children aged 24 to 72 months who frequent daycare centers found a relatively low prevalence of anemia: $11.2 \%^{23}$ and $15.4 \%^{24}$, respectively.

The prevalence of anemia among children who are exclusively breastfed was of $38.1 \%$. Important for preventing childhood anemia, breastfeeding for more than six months increases the risk of anemia since $90.0 \%$ of the iron requirement of the child comes from complementary foods ${ }^{25}$. A recent study on exclusive breastfeeding and iron-deficiency anemia found that $26.1 \%$ of the breastfed children were iron deficient, and $23.9 \%$ had iron-deficiency anemia ${ }^{26}$. Improving the iron reserves of the mother is an alternative to improve the iron reserves of breastfed children. Iron reserves at birth are smaller when the mother's reserves are low, reflecting the limited ability of the fetus to acquire iron. A study done in Indonesia with breastfed children aged four to six months found a prevalence of anemia of $37.0 \%(\mathrm{Hb}<10.0 \mathrm{~g} / \mathrm{dL})$, having as associated factor the mother's hemoglobin level27-29.

Among children aged 6 to 24 months, the prevalence of anemia was $43 \%$, and the association was statistically significant.

Above six months, the high prevalence can be explained by the depletion of the body's iron reserves acquired during intrauterine life along with the higher nutritional requirement due to faster growth. Together with a delayed introduction of high-iron foods, this constitutes a scenario that facilitates the development of anemia in this life stage ${ }^{30}$.

Qualitative or quantitative deficiency of dietary iron stemming from low iron intake or low 
bioavailability in foods has been pointed out as the most common cause of anemia ${ }^{31}$. In this perspective, we assessed exposure to food insecurity at the household, a hypothesis in the scenario of social inequalities that can explain the high prevalence of iron-deficiency anemia. The result, regardless of the statistically insignificant association, indicated that a slight improvement in the food insecurity situation of the family decreased the risk of anemia.

The concept of Food and Nutrition Security (FNS) in Article 3 of the Food and Nutrition Security Law is defined as:

The realization of everyone's right to regular and permanent access to quality foods, in adequate amounts, without compromising access to other essential needs, based on food practices that promote health, respect cultural diversity, and that are socially, economically, and environmentally sustainable (National Food Security Council, Law n 11.346/15/ 09/2006) $)^{32}$.

Food security is first and foremost a right to life and being exposed to an inappropriate diet or not having the means to acquire an appropriate diet is an affront and a violation of an established right. If on the one hand proper food is an individual right and ensuring FNS a state obligation, on the other hand identifying food insecurity of population groups in different locations is imperative, since it allows the planning of actions that materialize the condition for citizenship ${ }^{33,34}$

The situation of food security, that is, a situation in which there is no food restriction of any kind in the household, was identified in $44.8 \%$ of the households ${ }^{13,34}$. However, children living in these households presented a prevalence of anemia of $34.5 \%$.

Severe food insecurity, a situation in which food restriction is such that the children in the household also experience hunger, was identified in $7.0 \%$ of the study households, with a prevalence of anemia of $47.1 \%$. In this scenario people live in a state of restriction, resulting from inadequate economic resources to allow a minimum level of consumption ${ }^{12}$.

The results regarding the food security situation, even though not statistically associated with anemia, show that anemia has disseminated throughout all social classes and in families from different income strata. However, the prevalence tends to be highest in the most socioeconomically vulnerable groups, as seen in a study conducted in a municipality located in the Brazilian Northeast region ${ }^{12}$.

Guarantee of income availability is unarguably one of the determinants of the level of food and nutrition security. However, finding that iron-deficiency anemia was present in $34.5 \%$ of the food-secure children evidences the importance of studying the singularities of its social distribution more thoroughly. As stated by Szarfarc 35: "It is essential to know exactly how socioeconomic condition impacts dietary iron and the mechanisms in which this nutrient determines its organic reserves and consequently, the blood hemoglobin level" (p.6).

In this sense, the results provide consistent data for new studies since desirable information, such as identification of the social determinants of anemia in children under 60 months of age, was not found. The study factors related to the outcome indicate that certain interventions outside of the health sector are possible, such as in the field of food security. Regarding the health area, the performance of studies at regular intervals with the same age group allows the creation of temporal series that help to discover effective interventions for the prevention of irondeficiency anemia in this group. The present study can be a first step in this direction.

\section{CONCLUSION}

The present study evidenced the high prevalence of a nutritional deficiency in children aged less than 60 months, which can markedly 
and perversely compromise the child's development. The study revealed a risky scenario that assumes different forms regarding iron-deficiency anemia: age (children younger than two years old), gender (being female), and not frequenting a daycare center are important factors that should be considered during these children's lives.

\section{A C KNOWLEDGEMENTS}

The authors thank Prof. Dr. Enrico Colossimo for designing the sampling strategy. This study was sponsored by the Health Department of the State of Minas Gerais, State Coordination of Food and Nutrition and General Coordination of the National Policy of Food and Nutrition, Ministry of Health.

\section{CONTRIBUTIONS}

MBMC LISBÔA conceived and designed the study, collected data, performed the statistical analyses, interpreted the results, and wrote the manuscript. EO OLIVEIRA performed the statistical analyses and interpreted the results. JA LAMOUNIER J reviewed the manuscript. CAM SILVA performed the statistical analyses, interpreted the results, and reviewed the manuscript. RN FREITAS interpreted the results and reviewed the manuscript.

\section{RE FERE NCES}

1. World Health Organization. Worldwide prevalence of anaemia 1993-2005: WHO Global Database on Anaemia. Geneva: WHO; 2008.

2. Rappaport S. Hematologia: introdução. São Paulo: Roca; 1990.

3. Braga J, Vitalle MS. Deficiência de ferro na criança. Rev Bras Hematol Hemoter. 2010; 32(Supl. 2):38-44.

4. Brasil. Ministério da Saúde. Pesquisa Nacional de Demografia e Saúde da Criança e da Mulher: relatório final. Brasília: Ministério da Saúde; 2008 [acesso 2009 maio 4]. Disponível em: www.saude. gov.br/pnds2006

5. Leal L, Batista Filho M, Lira P, Figueiroa J, Osório M. Prevalência da anemia e fatores associados em crianças de seis a 59 meses de Pernambuco. Rev Saúde Pública. 2011; 45(3):457-66.
6. Neuman N, Tanaka O, Szarfarc S, Guimarães P, Victora C. Prevalência e fatores de risco para a anemia no Sul do Brasil. Rev Saúde Pública. 2000; 34(1):56-63.

7. Netto M, Rocha D, Franceschini S, Lamounier J. Fatores associados à anemia em lactentes nascidos a termo e sem baixo peso. Rev Assoc Med Bras. 2011; 57(5):550-8.

8. Silva DG, Franceschini SCC, Priore SE, Ribeiro SMR, Szarfarc SC, Souza SB, et al. Anemia ferropriva em crianças de 6 a 12 meses atendidas na rede pública de saúde do município de Viçosa, Minas Gerais. Rev Nutr. 2002; 15(3):301-8. http://dx.doi.org/ 10.1590/S1415-52732002000300006

9. Fundação João Pinheiro. Belo Horizonte; 2013 [acesso 2013 ago 20]. Disponível em: www.fjp. gov.br

10. Roncalli AG, Frazão P, Pattussi MP, Araújo IC, Ely HC, Batista SM. Projeto SB2000: uma perspectiva para a consolidação da Epidemiologia em Saúde Pública. Rev Bras Odont Saúde Colet. 2000; 1(2):9-25.

11. Katz J. Sample-size implications for populationbased cluster surveys of nutritional status. Am J Clin Nutr. 1995; 61(1):155-60.

12. Oliveira J, Lira P, Andrade S, Sales A, Maia S, Batista Filho M. Insegurança alimentar e estado nutricional de crianças de São João do Tigre, no semiárido do Nordeste. Rev Bras Epidemiol. 2009; 12(3):413-23.

13. Segall-Corrêa AM, Pérez-Escamilla R, Maranha LK, Sampaio MFA, Yuyama L, Alencar F, et al. Relatório Técnico (versão preliminar). Acompanhamento e avaliação da segurança alimentar de famílias brasileiras: validação de metodologia e de instrumento de coleta de informação. Campinas: Unicamp; 2004.

14. Organizacion Panamericana de la Salud. Indicadores para evaluar las practicas de lactancia materna. Genebra: OMS; 1991.

15. Jellife $D B$. The assessment of the nutritional status of the community. Geneva: WHO; 1968.

16. World Health Organization. Bulletin of the World Health Organization. Geneva: WHO; 2006 [cited 2008 June 1]. Available from: www.who.int/bulletin

17. Duarte LS, Fujimori E, Minagawa AT, Schoeps FA, Monteiro RMJM. Aleitamento materno e níveis de hemoglobina em crianças menores de 2 anos em município do estado de São Paulo, Brasil. Rev Nutr. 2007; 20(2):149-57. http://dx.doi.org/10.1590/ S1415-52732007000200004

18. World Health Organization. $3^{\text {rd }}$ Report on the world nutrition situation: A report compiled from information available to the ACC/SCN. Geneve: WHO; 1997. 
19. World Health Organization, United Nations Children's Fund, United Nations University. Iron deficiency anaemia: Assessment, prevention and control. A guide for program managers. Geneva: WHO; 2001.

20. Castro T, Silva-Nunes M, Conde W, Muniz P, Cardoso M. Anemia e deficiência de ferro em pré-escolares da Amazônia Ocidental Brasileira: prevalência e fatores associados. Cad Saúde Pública. 2011; 27(1):131-42.

21. Vieira R, Ferreira H, Costa A, Moura F, Florencio T, Torres Z. Prevalência e fatores de risco para a anemia em crianças pré-escolares do Estado de Alagoas, Brasil. Rev Bras Saúde Mater Infant. 2010; 10(1):107-16.

22. Oliveira DR, Miguel ASB. A nova concepção de creche pós - LDB (Lei de Diretrizes e Bases da Educação Nacional - Lei n 9.394/96). Revista Fafibe. 2012 [acesso 2013 dez 8]; 5(5). Disponível em: http://www.unifafibe.com.br/revistafafibeonline

23. Castro TG, Novaes JF, Silva MR, Costa NB, Franceschini SCC, Tinoco ALA, et al. Caracterização do consumo alimentar, ambiente socioeconômico e estado nutricional de pré-escolares de creches municipais. Rev Nutr. 2005; 18(3):321-30. http:// dx.doi.org/10.1590/S1415-52732005000300004

24. Pedraza DF, Rocha ACD, Sousa, CPC. Crescimento e deficiências de micronutrientes: perfil das crianças assistidas no núcleo de creches do governo da Paraíba, Brasil. Ciênc Saúde Colet. 2013; 18(11):3379-90.

25. Agostoni C, Decsi T, Fewtrell M, Goulet O, Kolacek S, Koletzko B, et al. Complementary feeding: A commentary by the ESPGHAN Committee on Nutrition. J Pediatr Gastroenterol Nutr. 2008; 46(1):99-110.

26. Marques RFSV, Taddei JAAC, Lopez FA, Braga JAP. Breastfeeding exclusively and iron deficiency anemia during the first 6 months of age. Rev Assoc Med Bras. 2014; 60(1):18-22.
27. Bortolini G, Vitolo $M$. The impact of systematic dietary counseling during the first year of life on prevalence rates of anemia and iron deficiency at 12-16 months. J.Pediatr. 2012; 88(1):33-9.

28. Teixeira M, Lira P, Coutinho S, Eickmann S, Lima M. Influence of breastfeeding type and maternal anemia on hemoglobin concentration in 6-monthold infants. J Pediatr. 2010; 86(1):65-72.

29. De Pee S, Bloem MW, Sari M, Kiess L, Yip R, Kosen $S$. The high prevalence of low hemoglobin concentration among Indonesian infants aged 3-5 months is related to maternal anemia. J Nutr. 2002; 132(8):2215-21.

30. Netto MP, Rocha DS, Franceschini SCC, Lamounier JA. Fatores associados à anemia em lactentes nascidos a termo e sem baixo peso. Rev Assoc Med Bras. 2011; 57(5):550-8.

31. Silva S, Batista Filho M, Miglioli, T. Prevalência e fatores de risco de anemia em mães e filhos no Estado de Pernambuco. Rev Bras Epidemiol. 2008; 11(2):266-77.

32. Brasil. Presidência da República. Lei n 11.346, de 15 de setembro de 2006. Cria o Sistema Nacional de Segurança Alimentar e Nutricional - SISAN com vistas em assegurar o direito humano à alimentação adequada e dá outras providências. Diário Oficial da União. 2006; 18 set.

33. Valente FL. Direito humano à alimentação. São Paulo: Cortez; 2002.

34. Souza-Esquerdo VF, Bergamasco SMPP, Oliveira JTA, Oliveira ES. Segurança alimentar e qualidade de vida em assentamentos rurais. Segur Aliment Nutr. 2013; 20(1):13-23.

35. Szarfarc, SC. Políticas públicas para o controle da anemia ferropriva. Rev Bras Hematol Hemoter. 2010; 32(Supl. 2):2-7.

Received: May 23, 2014

Final version: November 3, 2014

Approved: November 17, 2014 
